\title{
An outline of the geology and petroleum systems of the Paleozoic interior basins of South America
}

Petrobras/E\&P - Av. Chile, 65 - 13th floor, 20035.900 - Rio de Janeiro - RJ - Brazil.

E-mail: ejmilani@ep.petrobras.com.br; zalan@ep.petrobras.com.br

\begin{abstract}
Although large sedimentary provinces, the South American intracratonic basins have not been characterized yet as repositories of significant mineral and energy wealths, compared to their counterparts in the Northern Hemisphere.
\end{abstract}

In the Paraná Basin, heart of industrialized Brazil, hydroelectric power derived from waterfalls developed on the Cretaceous basaltic cover, gemstones and rich soils both derived again from the basalts, and groundwater from Jurassic eolian sandstones are the main resources. Bituminous shales, and more recently, gas discoveries constitute secondary resources; gas seems to characterize the Argentinian Chaco-Paraná Basin. In the Solimões Basin, the development of significant reserves of gas, and less noticeably of oil, is hampered by the remoteness of the area and lack of a nearby market. For the same reasons, in the Amazonas Basin large reserves of evaporites lie untouched in the subsurface; recent gas discoveries made near the capital jungle of Manaus point to a brighter future for their exploitation. In the Parnaíba Basin, situated in a remote semi-arid region of Brazil, groundwater is the main exploited mineral resource.

Considering their geological characteristics, the small amount of exploration performed in these basins is in sharp contrast with their petroleum potential. Some of their deposits have barely been scratched, suggesting that these areas may be profitable for bold investors.

\section{Introduction}

The remnants of significant, mostly undisturbed, Paleozoic sedimentation all over the South American continent are preserved in five individual basins - four in Brazil and one in Argentina (Figure 1). The Brazilian basins are the Solimões, Amazonas, Parnaíba and Paraná, named after large rivers that flow along their main axes. The Argentinian Chaco-Paraná Basin is included in the wide sub-Andean flat area that spans all the western portion of the continent. These basins exhibit elliptical to semi-circular geometry with individual areas ranging from $500,000 \mathrm{~km}^{2}$ to more than $1,000,000 \mathrm{~km}^{2}$. Together, they cover an area of about $3,200,000 \mathrm{~km}^{2}$, surrounded by circa $3,800,000 \mathrm{~km}^{2}$ of exposures of three major Precambrian shields (Guyanas, Central Brazil and Atlantic). These tectonic units compose a large crustal province known as the South American platform, and, in association with the Andean belt and the adjacent subandean flats, constitute the bulk of the South American continent.
It is interesting to observe that to date no definitively convincing mechanism has been proposed to explain what the initial driving mechanism of the first subsidence was or to explain how these basins had their subsidence mechanisms reactivated during additional tectonic events, resulting in a pile of sedimentary and volcanic strata that can reach cumulative thickness of more than 7,000 m. Rifts are known below some of these interior basins. However, sometimes their much older ages, and eventually their restricted areal distribution, preclude the hypothesis of considering them as the direct predecessors of the overlying intracratonic sags. Proterozoic crustal stretching associated with their formation or Early Paleozoic extensional reactivation of the Precambrian structural grain have been commonly invoked to explain the initial subsidence mechanism. Additional subsidence would have been achieved either by different episodes of reactivation by crustal stretching, always utilizing the existing grain, or, by flexural mode due to the cratonward influence of distant, plate-margin collisional tectonics.

Whatever the driving mechanisms of the subsidence events, the depressions were filled with essentially siliciclastic sedimentary sections (with the notable exception of an evaporite-carbonate cycle in the Solimões and Amazonas) that correspond to large-scale Paleozoic transgressive-regressive cycles (Figure 2). In most of the basins, the first cycles usually show marked glacial influences with ages that vary between the late Ordovician (Paraná) and the Devonian (Solimões and Amazonas), depending on the location of the basin over the Gondwana supercontinent that always wandered close to the South Pole (Caputo and Crowell, 1985). In the case of the Paraná and Chaco-Paraná Basins this glacial influence reappeared strongly in the Pennsylvanian, during the inception of the third transgressiveregressive cycle. In all the five basins the last transgressive-regressive cycle is almost uniformly terminated by late Permian to Triassic continental red beds that mark the drying out of the interior sags and the definitive disappearance of the seas from the cratonic areas of South America. The Mesozoic history of these basins is recorded as continental sedimentary packages and large volumes of magmatic rocks.

Regarding the petroleum systems, in the four Brazilian interior sags the Devonian package holds the most important source rocks, in the form of marine black shales, with ages varying from Frasnian (Solimões, Amazonas and Parnaíba) to Emsian (Paraná); on the Argentinian side, similar conditions seem to exist for sourcing from the Devonian shales in the Chaco-Paraná Basin. Reservoirs are present at various stratigraphic levels. Sandstones deposited in different environments, with ages varying from the Devonian (Parnaíba), through the Carboniferous (Solimões and Amazonas), to the Permian (Paraná and Chaco-Paraná), constitute the primary reservoirs known in these basins. Trapping mechanisms are usually structural, and fault-propagation anticlines associated with contractional faults hold the majority of the reserves in the Solimões Basin. Folds of diverse natures, some of them related to igneous activity (Conceição et al., 1993), also trap the gas fields in the Paraná Basin. Several minor accumulations of a clear stratigraphic nature are responsible for flows of oil in the Devonian of the Solimões and Amazonas basins and in the Permian of the Paraná Basin. 


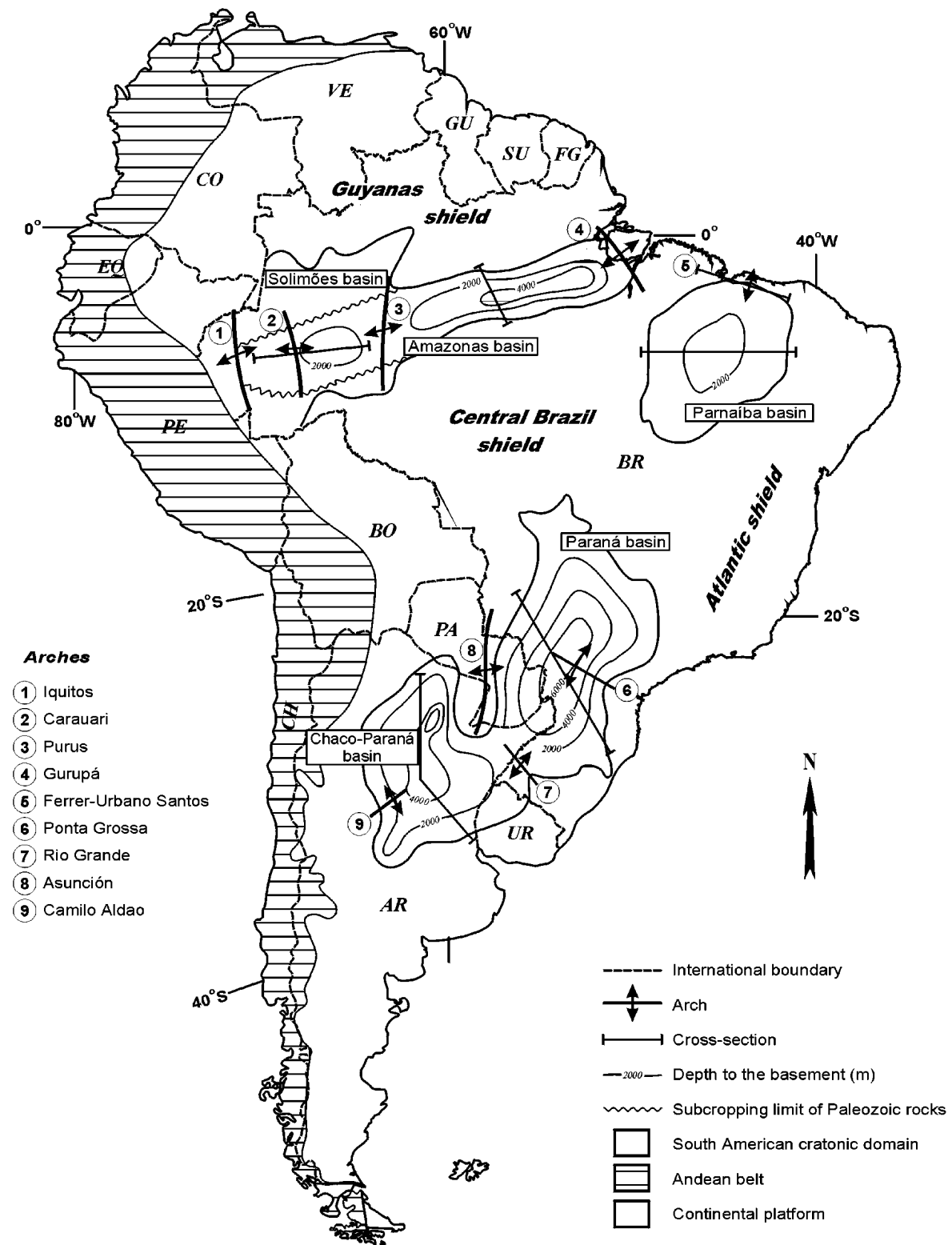

$0 \quad 1000 \quad 2000 \mathrm{~km}$

Figure 1 Situation map of the Paleozoic intracontinental sags of South America (compiled from various authors). Countries: FG-French Guyana, SU-Suriname, GU-Guyana, VE-Venezuela, CO-Colombia, EQ-Equator, PE-Peru, BO-Bolivia, CH-Chile, AR-Argentina, PA-Paraguay, UR-Uruguay, and BR-Brazil.

Maturation of source rocks in these basins has a remarkable aspect given by the thermal effect of diabases on the degree of conversion of the organic matter, on the level of such maturation and on the transformation of previously accumulated hydrocarbons. In some cases, maturation of the organic matter was achieved only by the additional thermal input of intruding diabases into the source rocks. In other cases, oil-window levels of maturation were catapulted into gas-window levels by intruding diabases. Furthermore, already formed oil pools were kept as such or were transformed into gas-pools, condensate/gas-pools or condensate/oil/gas-pools by intruding diabases, according to the relative increasing distance of the intrusions into the reservoirs. It is possible to state that in none of these basins can a simple model of maturation evolution, based solely on subsidence and uplift rates and thermal input derived from crustal stretching, explain any of the observed accumulations of petroleum and associated maturation indicators.

Tar sandstones were first identified in the Paraná Basin in the last decade of the 19th century. Shows of live oil were first found in the Amazonas Basin by drilling during the 1950s. Oil and gas were plentiful, and tar sands and bituminous shales were studied in great detail in the Paraná Basin during the 1960s and 1970s. The Solimões Basin does not even outcrop, and few wells with very little production had been drilled in it by the late 1970s. Interesting enough, the answer to the exploration efforts came in the opposite way to that of the discovery of hydrocarbon shows. The first commercial find of gas was in the Solimões Basin in the late 1970s. The first commercial find of oil and condensate occurred in the same basin in 1986, and the first flow of oil in 1988. The first commercial find of gas in the Paraná basin was in 1997, and in the Amazonas Basin early in 1999. No commercial discoveries have been made so far in the Parnaíba and ChacoParaná basins.

\section{Solimões Basin}

The Solimões Basin is situated in northern Brazil, right in the heart of the Amazon jungle and comprising an area of over $600,000 \mathrm{~km}^{2}$ (Figure 1). Only two-thirds of this area corresponds to the region of occurrence of Paleozoic strata $\left(400,000 \mathrm{~km}^{2}\right)$, the remainder being dominated by a sandy, Cretaceous-to-Recent continental cover that prevents outcrops of the Paleozoic successions in the basin. The Solimões Basin, together with its eastern counterpart, the Amazonas Basin, constitutes an impressive E-W oriented interior basin, 2,500 $\mathrm{km}$ long, $500 \mathrm{~km}$ wide and up to 5,000 m deep . The flexural arches of Iquitos and Purus separate the Solimões Basin from, respectively, the Acre Basin to the west and the Amazonas Basin to the east. Inside the Solimões Basin (Figure 3), a prominent NW-SE-striking positive feature (Carauari high) defines two subbasins (Eiras, 1996). Particularly during prePennsylvanian times, this structural high exerted decisive control on sedimentary thickness distribution and facies. The easternmost Juruá sub-basin, with a package of sedimentary rocks up to $3,800 \mathrm{~m}$ thick, holds most of the hydrocarbon reserves in Paleozoic cratonic sequences in South America so far identified.

The axis of the Solimões Basin is marked by the presence of the Solimões megashear zone (Caputo and Silva, 1990), a classic example of an intraplate deformation belt that comprises a fault-and-fold system in a $\mathrm{N} 70^{\circ}-80^{\circ} \mathrm{E}$ direction, with a total length of about 1,000 $\mathrm{km}$, caused by Jurassic to Cretaceous right-lateral wrenching. These faults are of a contractional nature, and in seismic sections they appear as simple high-angle reverse faults, without much lateral movement. Trending parallel to the faults, several narrow, faultpropagation anticlines hold dozens of petroleum accumulations. This set of structures constitutes the main structural style of hydrocarbon traps in this basin.

Four Paleozoic supersequences covered by two units, one Cretaceous and the other Early Cenozoic to Recent, constitute the strati- 


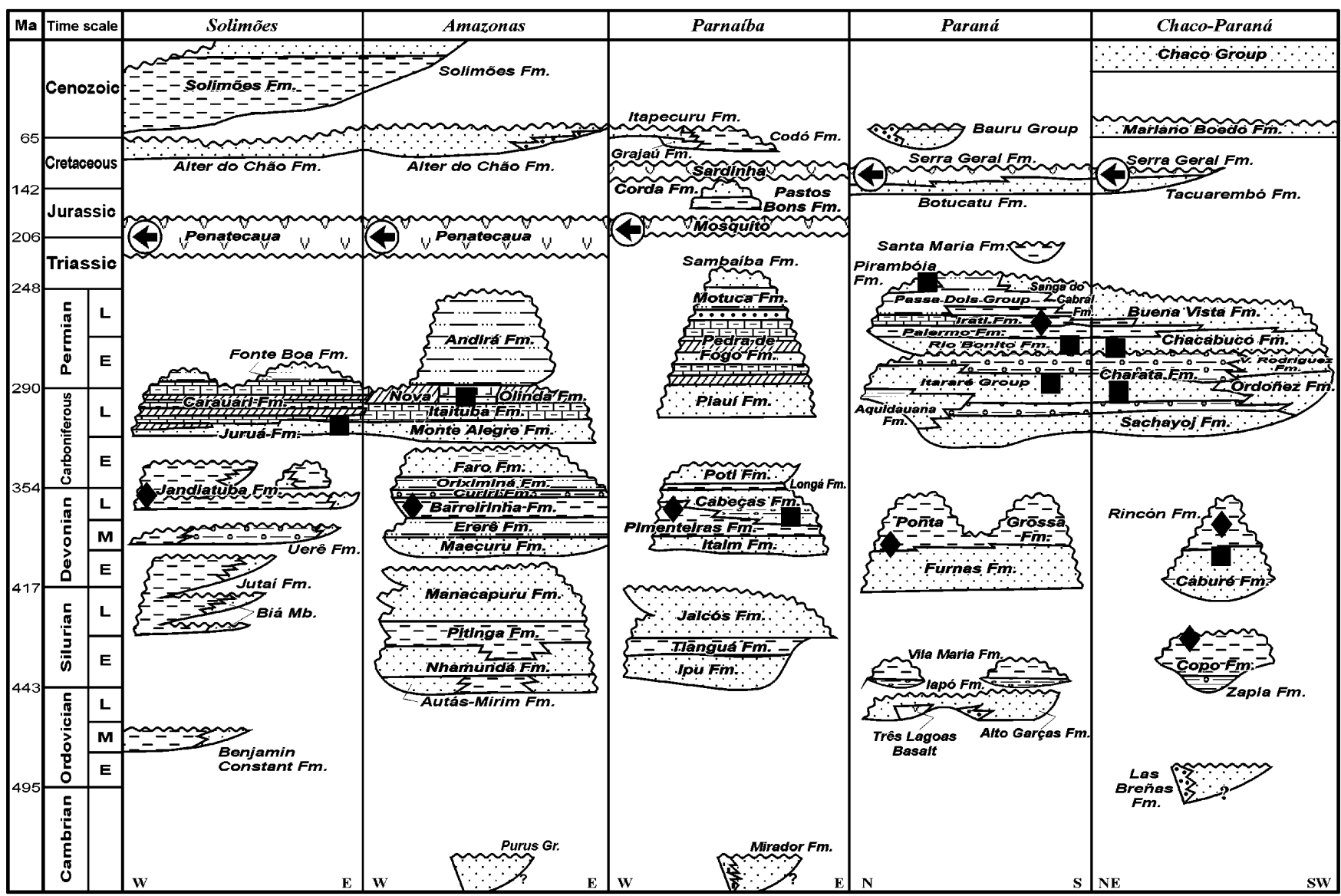

Figure 2 Stratigraphic summary of the Paleozoic intracontinental sags of South America (compiled from various authors). Lithologic representations are of common use ( $v$ - magmatic rocks, o- diamictites). Legend for petroleum systems elements: lozenges - source beds; squares - reservoirs; circled arrows indicate the critical moment, when most of hydrocarbon was generated, migrated and accumulated, or even strongly remobilized from previously existent pools. Geological time scale simplified from Gradstein and Ogg (1996).

graphic framework of the Solimões Basin (Figure 2). The Paleozoic sedimentary units were intruded by igneous rocks during the Late Triassic and Early Jurassic, an event known as the Penatecaua magmatism (Eiras et al., 1994).

The Ordovician Sequence is represented by the continental-toshallow marine siliciclastic rocks of the Benjamin Constant Formation (Eiras et al, 1994). The Silurian-Devonian Sequence follows, constituted by a package of dark gray marine shales (Jutaí Formation) that grades eastwards into coastal sandstones and micaceous siltstones (Biá Member) where the sequence onlaps the Carauari high. The Uerá (silexites and sandstones) and Jandiatuba (organicrich black shales, diamictites and sandstones) formations span the Emsian-Tournaisian range (Quadros et al., 1992) and constitute the Devonian-Carboniferous Sequence. The package is considered of shallow marine origin, transgressive up to the Frasnian and remarkably regressive upwards. Some glacial influence on sedimentation is interpreted for this interval, supported by the presence of lenticular bodies of diamictites (Jaraqui Member). The sequence may reach 300 meters in thickness.

A partial continentalization of the Solimões Basin took place during the initial stages of the Carboniferous-Permian Sequence, allowing deposition of a blanket of eolian sandstones (Juruá Formation) that grades into a thick (up to $1,300 \mathrm{~m}$ ) package of rhythmic carbonates and evaporites (Carauari Formation). The sequence is ended by a section of fluvial and lacustrine red beds (Fonte Boa Formation). During the accumulation of the Carboniferous-Permian Sequence, for the first time the Purus arch was completely surpassed, linking the Solimões and Amazonas Basins into a single depositional site (Caputo and Silva, 1990).
In the Solimões Basin, the known petroleum system includes source rocks from the Jandiatuba (mostly), Jaraqui and Ueré formations, attaining thickness of $50 \mathrm{~m}$ and reaching up to $8 \%$ of TOC (average of 6\%) in the first. The eolian sandstones of the Juruá Formation have been found to be the best, and practically the only, reservoir in the basin, with secondary porosity (dissolution of calcite and anhydrite) that may reach up to $22 \%$. In the Solimões Basin, the degree of maturation of the source beds is very sensitive to the presence and proximity of intrusive bodies, this being a key factor for exploration in the area. Magmatism exploded during Late Triassic to Early Jurassic, when most of the generation, expulsion, migration and transformation of petroleum took place. Present traps were formed during the dextral wrenching Juruá event, in the Jurassic to Early Cretaceous period, remobilizing and trapping petroleum that had been accumulated in earlier formed traps (of possible Pennsylvanian/Permian age).

\section{Amazonas Basin}

This basin covers about $500,000 \mathrm{~km}^{2}$ of northern Brazil, lying completely under the Amazon forest (Figure 1). Its major axis trends East-West and its strata onlap the Precambrian provinces of the Guyanas shield to the north and of the Central Brazil shield to the south, cropping out along both sides of the basin. To the east, the Amazonas Basin is separated from the Mesozoic Marajó rift by the Gurupá arch. To the west, the Amazonas Basin is separated from the Solimões Basin by the roughly N-S-trending Purus arch. In its depocenter, the basin holds a stratigraphic record up to 5,000 meters thick. 
The basement of the Amazonas Basin is dominantly constituted by igneous and metamorphic rocks, but some Proterozoic rift successions of alluvial, fluvial and lacustrine sedimentary rocks occur in its western portion, composing the Purus Group. The existence of strong, positive gravity anomalies coincident with the axis of the syneclise, suggesting shallow ultrabasic bodies, together with the underlying aulacogenic strata, led to the classic interpretation of a rifting mechanism as the initial driving mechanism for the subsidence of the Amazonas Basin.

The stratigraphic framework of the Amazonas Basin includes three Paleozoic supersequences covered by Cretaceous to Recent continental clastics (Cunha et al., 1994). The Ordovician-Devonian Sequence (Figure 2), or Trombetas Group, is composed of marine shales, sandstones and diamictites. This sedimentation was in part accumulated under the yoke of the Late Ordovician-Early Silurian glaciation that affected large portions of Gondwana.

A second transgressive-regressive cycle is recorded in the Amazonas Basin by the sedimentary rocks of the Urupadi and Curuá Groups, together composing the Devonian-Carboniferous Sequence. This sequence includes Early Devonian coastal sandstones and shallow marine shales in its basal portion, followed by an up to 250 meter-thick package of laminated black shales (Barreirinha Formation) of Frasnian age, considered as the record of maximum paleobathymetric conditions during the history of the basin. A controversial Famennian glacial cycle (Daemon and Contreiras, 1971) is interpreted from the record of the Curiri Formation made of diamictites and associated shales and siltstones. The upper units of this sequence, the Oriximiná and Faro formations, record the regressive portion of the cycle. Regional erosive processes affected the basin during the final stages of the Mississipian.

A renewed cycle of subsidence and sediment accommodation took place from the Pennsylvanian onwards (Figure 3). The lowermost package of the CarboniferousPermian Sequence, or Tapajós Group, is a blanket of eolian sandstones (Monte Alegre Formation) covered by a section of carbonates and evaporites (Itaituba and Nova Olinda Formations), with subordinated sandstones and shales that may reach 1,600 meters in thickness. The cycle is closed by continental red beds (Andirá Formation) of Permian age (Rodrigues et al., 1993). East-West regional extension allowed a pervasive intrusion of magmatic bodies during the Early Jurassic (Mizusaki et al., 1992).

In terms of source rocks (black shales of the Barreirinha Formation) and cap rocks (evaporites of the Pennsylvanian age), the similarities with the Solimões Basin are great. However, in the Amazonas Basin gas was found in lenticular sandstones of the Nova Olinda Formation. Different structural styles should be responsible for the traps found in the basin, since an organized belt of deformation like the Solimões megashear zone, the main provider of trapping for petroleum in the adjacent basin, seems to be absent here. The most probable ones are extensional fault-blocks, salt tectonics and transcurrent movements during the Cenozoic. Significant differences with respect to the Solimões Basin may also occur regarding the maturation of the organic matter, as studies indicate an early maturation of the organic matter by normal subsidence since the Late Carboniferous (Gonçalves et al., 1995), with a peak in the Late Permian. The thermal effects of the Mesozoic magmatism accelerated rates of maturation or promoted jumps in certain areas into higher thermal levels.
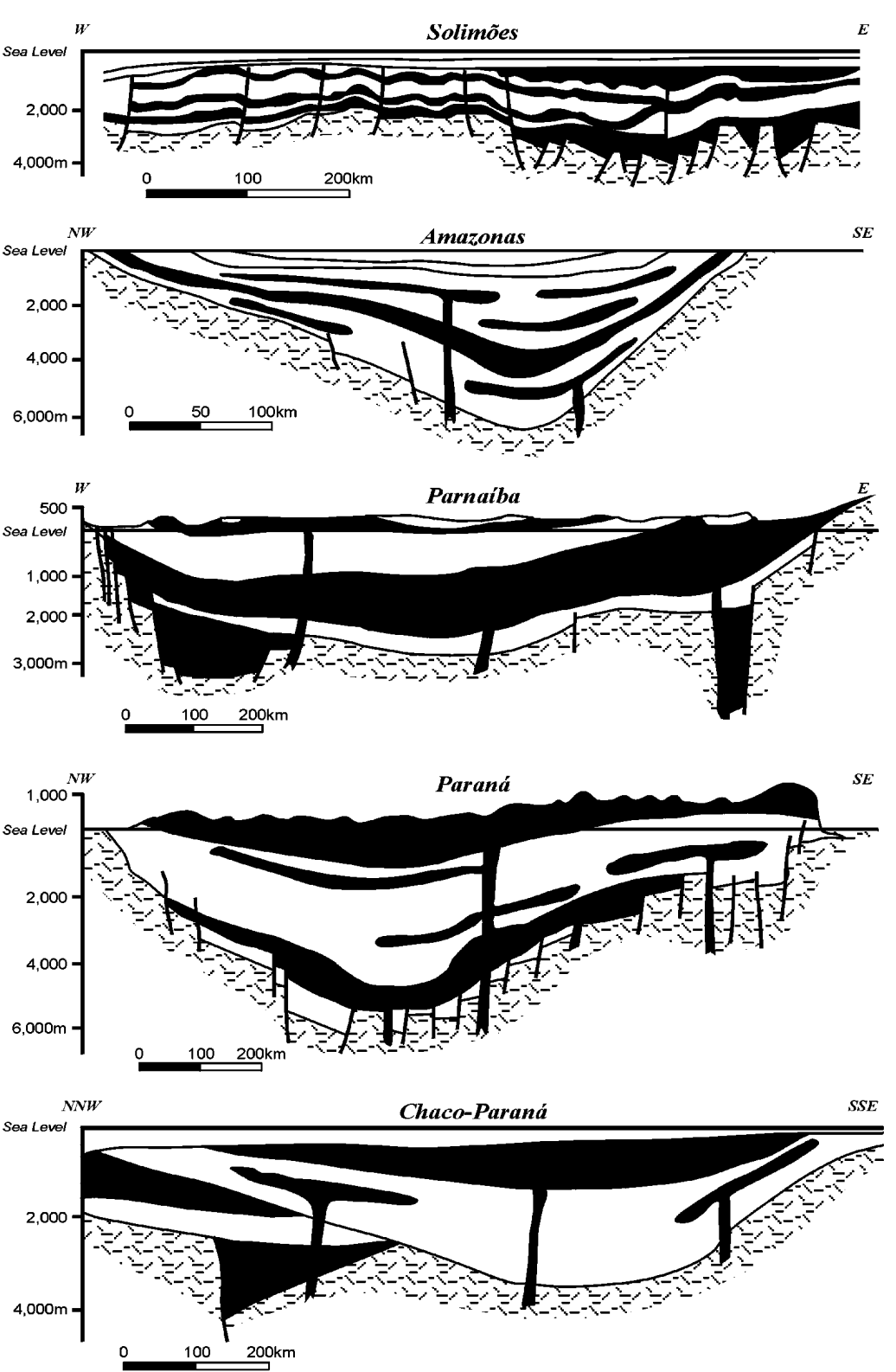

Figure 3 Geological cross-sections of the Solimões Basin (Eiras, 1996), Amazonas Basin (Gonçalves et al., 1995), Parnaíba Basin (Góes et al., 1993), and Paraná Basin (Raffaelli et al., 1996, Milani and Zalán, 1998). Diagram for the Chaco-Paraná Basin is conceptual.

\section{Parnaíba Basin}

The Parnaíba Basin is located in the western portion of the northeastern region of Brazil (Figure 1), occupying an area as large as $600,000 \mathrm{~km}^{2}$. It is a circular sag holding a total sedimentary section (Figure 2) of about 3,500 meters thick in its depocenter, and is framed by an almost continuous ring belt of outcrops that provides excellent conditions for observation of its infilling rocks. The FerrerUrbano Santos arch, a flexural positive feature related to the Meso- 
zoic opening of the Equatorial Atlantic ocean, defines the northern limit for the Parnaíba Basin; where the Atlantic rifting broke the previous connection of the Parnaíba depocenter with analogous basins in northwestern Africa.

Geophysical data, together with subsurface information, revealed the existence of a basal package of arkoses confined inside Late Proterozoic/Cambrian N-S-trending grabens opened in the crystalline basement. This sandy section (Mirador Formation) of poorly constrained age was interpreted as being the rift sequence precursor of the Parnaíba Basin (Góes et al., 1990). A flexural syneclise developed afterwards, giving the final steer's head geometry for the basin, but an influence of the initial rift architecture on the location of cratonic sedimentation depocenters was felt up to the Early Carboniferous.

The structural framework of the basin is quite peculiar, because its eastern/southern portion is cut and it is strongly influenced by the most important fault zone of continental scale in Brazil: the Transbrasiliano fault zone. From north to south in a NE-SW trend, this fault zone runs across Brazil for 3,000 km, from the continental margin of the Equatorial Atlantic, where it is cut by the Romanche Oceanic Fracture Zone, into Paraguay, crossing the interior basins of Parnaíba, Paraná and Pantanal. Within the Parnaíba Basin the fault zone is expressed as a wide band of surface and subsurface deformation that controlled old aulacogens and Paleozoic depocenters (Figure 3). Outside its limits, the deformation in the basin is not strong, and it is mostly represented by subtle fault-block tectonics, where normal and reverse faults created associated closures. Intrusion of sills is abundant and widespread, and also is responsible for several kinds of related deformation.

The stratigraphic record of the Parnaíba Basin (Figure 2) encompasses three major Paleozoic and two Mesozoic supersequences (Góes and Feijó, 1994). The basal one, mainly of Silurian age, is represented by rocks of the Serra Grande Group, including sandstones and subordinated siltstones, shales and diamictites (Ipu Formation), grey shales, siltstones and micaceous coastal sandstones of Wenlock age (Tianguá Formation) and coarse-grained sandstones of a braided alluvial-fluvial depositional system (Jaicós Formation). The entire package constitutes a complete transgressive-regressive cycle of sedimentation.

The Devonian Supersequence (Canindé Group, Eifelian-Tournaisian) has tide and storm-related sediments (Itaim Formation), organic-rich black shales up to 300 meters thick (Pimenteiras Formation), fine-grained shallow marine sandstones with local diamictites (Cabeças Formation), fluvial sandstones (Longá Formation) and an Early Carboniferous heterolythic package of fine-grained sandstones and shales (Poti Formation). The inception of the Pennsylvanian sedimentation in the Parnaíba Basin was marked by profound modifications in both environmental and tectonic characteristics (Góes and Feijó, 1994). Depocenters changed from an elongated graben-controlled geometry to a circular configuration, and the condition of a temperate, open marine basin turned into a restricted sea under progressive aridity (Caputo, 1984). The Balsas Group, or Carboniferous-Triassic Supersequence, is made up of a clastic-evaporitic succession of sedimentary rocks with fine- to medium-grained sandstones, brown shales and subordinated limestones (Piauí Formation), rhythmites with alternating oolitic limestones, white anhydrites and yellow sandstones (Pedra de Fogo Formation), brown siltstones, medium-grained sandstones and some anhydrite (Motuca Formation) and eolian sandstones (Sambaíba Formation).

Two main pulses of magmatic activity took place in the Parnaíba Basin during the Mesozoic. Both intrusive emplacements and volcanic flows occurred, the former being preferentially found inside the rocks of the Canindé Group. The first magmatic cycle, from the Triassic-Jurassic and correlated to the Penatecaua magmatism of the Solimões and Amazonas Basins (opening of the North Atlantic), is known as the Mosquito Formation. The second one, dated to the Early Cretaceous (opening of the South Atlantic), constitutes the Sardinha Formation.

The petroleum potential of the Parnaíba Basin is related to source rocks present in the dark-gray-to-black shales of the
Pimenteiras Formation, of Givetian/Frasnian age, with TOC of about $2.0-2.5 \%$. The shales are in direct contact with the main reservoirs, the overlying deltaic/tidal/shallow marine sandstones of the Cabeças Formation of Frasnian/Famennian age, deposited in a periglacial environment. The source rocks are usually immature in terms of thermal evolution, with the exception of the surroundings of igneous intrusions that seem to constitute the only source of heat capable of promoting sufficient thermal maturation necessary for the generation of large quantities of hydrocarbons. This last item is the major concern of the petroleum geology of the basin, since there are multiple levels of reservoirs and seal rocks. Although the basin is practically undisturbed, some major trends of faults are known, especially above the older grain of subjacent rifts.

\section{Paraná Basin}

The Paraná Basin is located in southern Brazil, where it covers an area of over $1,000,000 \mathrm{~km}^{2}$, and reaches the neighbouring countries of Paraguay, Argentina and Uruguay, with an additional area of $400,000 \mathrm{~km}^{2}$ (Figure 1). The basin has a NNE-SSW-trending elliptical shape with two-thirds of its surface covered by Mesozoic basaltic lavas. The infilling sedimentary strata appear along a 5,500-km belt of outcrops shaped during Mesozoic-Cenozoic times, almost completely framing the syneclise. The stratigraphic record (Figure 2) of this huge basin exceeds 7,000 $\mathrm{m}$ in thickness in the central depocenter, just below the river that lends its name to the basin.

The eastern flank of the Paraná Basin corresponds to a crustal region deeply affected by the South Atlantic rifting and the opening of the ocean, so that uplift and erosion have been responsible for the removal of great amounts of Paleozoic sedimentary rocks from that area. The western border of the basin is defined by the Asunción arch, a flexural bulge related to the loading of the Cenozoic Andean thrust sheets in nearby Argentina and Bolivia. To the north, as well as to the south, the strata of the Paraná Basin onlap crystalline rocks of cratonic provinces in the Precambrian basement (Figure 3).

The Late Ordovician inception and further evolution of the Paraná Basin in the continental interior of Gondwana had a close relationship to the development of the Gondwanides, a large Phanerozoic mobile belt that was the site of a series of orogenic cycles (Ramos et al., 1986). Such orogenies seem to have exerted a decisive influence on the creation of accommodation space for the various supersequences that fill the Paraná Basin (Milani, 1997; Milani and Ramos, 1998), as well as on the deformational history of the basin (Zalán et al., 1990), by means of intraplate reactivation of SW-NE-trending pre-existent crustal weakness zones (inherited from the Brasiliano orogenic cycle) or cratonward propagation of regional flexural subsidence.

Six major, second-order allostratigraphic units or supersequences (Milani, 1997) are recognized in the stratigraphic record of the Paraná Basin (Figure 2): Rio Ivaí (Caradoc-Llandovery), Paraná (Lockovian-Frasnian), Gondwana I (Westphalian-Scythian), Gondwana II (Anisian-Norian), Gondwana III (Upper Jurassic-Berriasian), and Bauru (Aptian-Maastrichtian). Three of them correspond to Paleozoic transgressive-regressive cycles, and the others are Mesozoic continental sedimentary packages with associated igneous rocks.

The Rio Ivaí Supersequence begins with a basal sandy unit (Alto Garças Formation) up to 300 meters thick, followed by some tens of meters of diamictites (Iapó Formation) that record the Late Ordovician-Early Silurian glaciation of Gondwana. The uppermost unit of the supersequence, the Vila Maria Formation, consists of micaceous shales and fine-grained sandstones with a Llandovery content of macro and microfossils.

The Devonian package of the Paraná Basin (Paraná Supersequence) spans the range Pragian-Frasnian, and is composed of a blanket of coarse-grained, kaolinite-rich sandstones (Furnas Formation) covered by a shaly section with subordinated siltstones and deltaic sandstones (Ponta Grossa Formation). The Devonian shales, 
particularly their lowermost section of the Emsian-Eifelian age, hold the endemic Malvinokaffric fauna of invertebrates (Melo, 1988). Bioturbation is a dominant characteristic in these shales, but some intervals of black laminated rocks also occur, recording maximum paleobathymetric conditions of the Devonian sea.

The Gondwana I Supersequence, among all second-order allostratigraphic units, includes the biggest sedimentary volume of the Paraná Basin, with a thickness that reaches a maximum of about 2,500 meters. This is a sedimentologically heterogeneous and complex package, recording the great paleoenvironmental changes through time that occurred in Gondwana from the glacial epochs in the Pennsylvanian to the dry and arid Triassic times.

The lowermost section of the Gondwana I Supersequence is composed of a package of glaciogenic rocks (Itararé Group and Aquidauana Formation), including diamictites, turbiditic sandstones, conglomerates and subordinate varvites and tillites of 1,500 meters of maximum thickness. This section constitutes the thickest and stratigraphically most complete record of the Late Carboniferous-Early Permian glaciation of Gondwana, spanning the Westphalian and the Artinskian. Following the glaciogenic package comes a transgressive section (Guatá Group) that includes deltaic sandstones and coals of Artinskian-Kungurian age (Rio Bonito Formation), as well as siltstones and shales (Palermo Formation). In the Kazanian, a succession of bituminous shales and limestones with minor evaporites was deposited (Irati Formation). The Gondwana I Supersequence is terminated by a thick package of red beds (Rio do Rasto Formation), accumulated at the dawn of the Mesozoic. Fluvial and lacustrine red beds of local occurrence constitute the Gondwana II Supersequence of the Paraná Basin, and hold an abundant fossil content of Middle to Late Triassic tetrapods.

Huge seas of eolian dunes (Botucatu Formation) with a widespread regional distribution dominated the Jurassic scenario of the Paraná Basin, followed by the Early Cretaceous magmatism (predominantly basaltic in nature, with some acid and intermediate terms) of the Serra Geral Formation; together, these units compose the Gondwana III Supersequence. The Upper Cretaceous Bauru Supersequence is a package of alluvial, fluvial and eolian sedimentary rocks that closed the depositional history of the Paraná Basin. This post-basalts section has a Senonian fossil content that includes elements of the Chelonia, Crocodilia and Dinosauria genus.

The most important petroleum system of the Paraná Basin encompasses Devonian black shales of the Ponta Grossa Formation (Emsian, with TOC between $1.5 \%$ and $2.5 \%$, with peaks as highs as $4.6 \%$, Type II organic matter) as the source rock, sourcing mostly gas into Late Carboniferous to Early Permian glaciogenic sandstones of the Itarare Group, and also into the coastal sandstones of the Rio Bonito Formation, of Early Permian age (Milani and Zalán 1998). The first is sealed by Mesozoic diabase sills and the second by argillaceous cap rocks. This Devonian source rock is of the same age as the source rocks in other important petroleum-producing areas of South America, such as the Chaco Basin in northwestern Argentina and Bolívia.

A second petroleum system in the basin includes sourcing of oil from the Kazanian organic-rich shales of the Irati Formation and accumulation in the coastal sandstones of the Early Permian Rio Bonito Formation (mainly) and eolian/fluvial sandstones of the Permian/Triassic Pirambóia Formation. The first is capped by argillaceous rocks, while the second is sealed by basaltic lava flows. Traps are mostly structural in nature. The Irati-Pirambóia petroleum system is responsible for about 20 known exhumed accumulations consisting of bituminous sandstones on the eastern rim of the basin, in the State of São Paulo. Several million barrels of biodegraded inplace oil in the form of tar sands are mapped throughout an area of a few thousand square kilometers. Uncountable shows of oil $\left(22^{\circ}-33^{\circ}\right.$ API) and minor amounts of gas in the basin, especially in its southern portion, are also related to the Irati-Rio Bonito petroleum system. The Irati Formation is a widespread, moderately thin but extremely organic rich source rock presenting TOC between $8 \%$ and $13 \%$, with peaks as high as $24 \%$ (organic matter type I).
Maturation of both petroleum systems is non-conventional, in the sense that it was greatly influenced by the heat derived from the diabase sills that intruded into or was close to the source rocks. Detailed studies indicate that most of the generation of the Irati Formation was only achieved by the direct contact of immature shales and intruding diabases, with thicknesses of a few dozen meters, that imprinted a thermal stress of the liquid hydrocarbons level. For the Devonian, on the other hand, the cumulative thickness of intrusive rocks was always much larger (around several hundred meters); thus imparting thermal regimes that cracked all bitumen (in immature or already mature shales) and hydrocarbons (in pools formed prior to the intrusions) into mostly gas fractions.

\section{Chaco-Paraná Basin}

The Chaco-Paraná Basin has an area of about $500,000 \mathrm{~km}^{2}$, and is an elliptical-shaped depocenter with its main axis oriented ENE-WSW (Figure 1). The surface expression of the basin is mostly featureless, a flat plain covered by Quaternary to Recent fluvial deposits. Its northeastern portion is marked by the presence of Cretaceous basalts correlative to those developed mostly in the Brazilian Paraná Basin. To the west, the basin is limited by the Pampean ranges, a system of thrusted Precambrian basement rocks uplifted in the Neogene by the Andean orogeny.

Subsidence and sediment accumulation began during Ordovician(?)-Silurian times (Figure 2). A deep, SW-NE-striking depocenter named the Las Breñas low is known in the central portion of the basin (Pezzi and Mozetic, 1989), appearing as an asymmetric graben with structural dip of the basement to the NW, against its master fault (Figure 3). The nature and age of the filling of this graben, a structural depocenter that holds a package of probably sedimentaryigneous rocks up to 5,000 meters thick, are still speculative topics, and a reasonable hypothesis based on seismo-stratigraphic analysis is that of an immature, basal siliciclastic package followed by a mixed, quartz-carbonate marine section culminating in a deeper marine interval. The complete package has a range of ages probably confined inside the Early Paleozoic.

The Silurian-Devonian package of the Chaco-Paraná Basin expanded the depositional area with respect to the previous unit. It includes local remnants of the Late Ordovician-Early Silurian glaciation in the Zapla Formation; a package of micaceous, Silurian dark gray shales, the Copo Formation; and the classic Devonian succession of southwestern Gondwana's basins, constituted by a basal section of continental-to-shallow marine sandstones known as the Caburé Formation that grades into the marine black shales of the Rincón Formation. The total thickness of the Devonian package surpasses 1,200 meters.

Permian-Carboniferous sequences are up to $2,300 \mathrm{~m}$ thick in the Chaco-Paraná Basin (Russo et al., 1987), and appear in two distinct sub-basins. In the western Alhuampa subbasin, the lowermost unit, the Stephanian-Asselian Sachayoj Formation, consists of medium-grained sandstones interbedded with black shales, followed by a package of diamictites up to 550 meters thick, constituting the Charata Formation, whose characteristics indicates a cold and humid, glacial-periglacial environment. The transitional Chacabuco Formation is composed of siltstones and shales, sometimes bituminous, and lenticular beds of limestones. A similar sedimentary succession appears in the eastern sub-basin. There the lowermost stratigraphic unit, 1,540 m thick, made of white sandstones and grey-toblack shales with associated diamictites, is named the Ordoñez Formation; and the upper one, a 660 meter-thick package of sandstones, siltstones and shales, is known as the Victoriano Rodríguez Formation.

During the early Mesozoic, the region of the Chaco-Paraná Basin underwent a broad crustal upwarp as the initial manifestations of the South Atlantic rifting. Fluvial and eolian sediments up to $400 \mathrm{~m}$ thick accumulated widely and constituted the Tacuarembó Formation, followed by the intrusion and outpouring of the Early Cretaceous dia- 
bases and basalts of the Serra Geral Formation. In the Paleocene, large portions of the Chaco-Paraná Basin were drowned during a brief incursion of the sea, and a section of about 350 meters of average thickness of gray calciferous mudstones and sandstones, with subordinated beds of gypsum was deposited, composing the Mariano Boedo Formation. From Miocene to Recent times, a continental package of sands invaded the basin from its western side, constituting the Chaco Group, a more than 2,000 m thick wedge of poorly consolidated postorogenic sedimentary rocks derived from the Andean belt.

\section{Acknowledgements}

The authors acknowledge their debt to Petrobras for permission to publish this paper.

\section{References}

Caputo, M.V., 1984. Stratigraphy, tectonics, paleoclimatology and paleogeography of Northern basins of Brazil: Santa Barbara, University of California, unp. PhD Thesis, $583 \mathrm{p}$.

Caputo, M.V. and Crowell, J.C., 1985, Migration of glacial centers across Gondwana during Paleozoic Era: Geological Society of America Bulletin, v. 96, no.2, pp. 1020-1036.

Caputo, M.V. and Silva, O.B., 1990, Sedimentação e tectônica da Bacia do Solimões, in Raja Gabaglia, G.P. and Milani, E.J., eds., Origem e evolução de bacias sedimentares: Rio de Janeiro, Petrobras, pp. 169-193.

Conceição, J.C.J., Zalán, P.V., and Dayan, H., 1993, Deformação em rochas sedimentares induzidas por intrusões magmáticas: classificação e mecanismos de intrusão: Boletim de Geociências da Petrobras, v. 7, no. 1/4, pp.57-92.

Cunha, P.R.C., Gonzaga, F.G. Coutinho, L.F.C., and Feijó, F.J., 1994, Bacia do Amazonas: Boletim de Geociências da Petrobras, v. 8, no. 1, pp. 4755.

Daemon, R.F. and Contreiras, C.J.A., 1971, Zoneamento palinológico da Bacia do Amazonas: 25th Congresso Brasileiro de Geologia, São Paulo, Abstracts Volume, v. 3, pp. 79-88.

Eiras, J.F., Becker, C.R., Souza, E M, Gonzaga, F.G., Silva, J.G.F., Daniel, L.M.F., Matsuda, N.S., and Feijó, F.J., 1994, Bacia do Solimões: Boletim de Geociéncias da Petrobras, v. 8, no. 1, pp. 17-45.

Eiras, J.F. 1996, Influéncia tectônica do arco de Carauari na sedimentação fanerozóica da bacia do Solimões, Norte do Brasil: 39th Congresso Brasileiro de Geologia, Salvador, Abstracts Volume, v. 1, pp. 50-53.

Góes, A.M.O., Souza, J.M.P., and Teixeira, L.B., 1990, Estágio exploratório e perspectivas petrolíferas da Bacia do Parnaíba: Boletim de Geociências da Petrobras, v. 4, no. 1, pp. 55-64.

Góes, A.M.O. and Feijó, F.J., 1994, Bacia do Parnaíba: Boletim de Geociências da Petrobras, v. 8, no. 1, pp. 57-67.

Gonçalves, F.T., Gonzaga, F.G., Coutinho, L.F.C., and Trigüis, J.A., 1995, Petroleum geochemistry of the Amazonas Basin, Brazil: oil-source correlation and assessment of hydrocarbon generation and expulsion: 17th International Meeting on Organic Geochemistry, San Sebastian, Selected Papers, pp. 444-446.

Gradstein, F., and Ogg, J., 1996, A Phanerozoic time scale: supplement to Episodes v. 19, no. 1-2.

Melo, J.H.G., 1988, The Malvinokaffric realm in the Devonian of Brazil in McMillan, N.J., Embry, A.F., and Glass, D.J., eds., Devonian of the world: Calgary, Canadian Society of Petroleum Geologists, Memoir 14, v. I, pp. 669-704.

Milani, E.J., 1997, Evolução tectono-estratigráfica da Bacia do Paraná e seu relacionamento com a geodinâmica fanerozóica do Gondwana sul-ocidental: Porto Alegre, Rio Grande do Sul Federal University, unp. PhD thesis, $255 \mathrm{p}$.

Milani, E.J. and Ramos, V.A., 1998, Orogenias paleozóicas no domínio sulocidental do Gondwana e os ciclos de subsidência da Bacia do Paraná: Revista Brasileira de Geociências, v. 28, no. 4, 527-544.

Milani, E.J. and Zalán, P.V., 1998, Brazilian Geology Part 1: the Geology of Paleozoic Cratonic Basins and Mesozoic Interior Rifts of Brazil: Rio'98 AAPG International Conference \& Exhibition, Rio de Janeiro, Short Course Notes, v. 1, 186 p.

Mizusaki, A.M.P., Wanderley Fo, J.R., and Aires, J.R., 1992. Caracterização do magmatismo básico das bacias do Solimões e do Amazonas: Rio de Janeiro, Petrobras, 45 p.
Pezzi, E.E. and Mozetic, M.E., 1989, Cuencas sedimentarias de la region Chacoparanense, in Chebli, G. and Spalletti, L., eds., Cuencas sedimentarias argentinas: Universidad Nacional, Tucuman, Correlacion Geologica 6, pp. 65-78.

Quadros, L.P., Melo, J.H.G., and Grahn, C.Y., 1992, Bacia do Solimões, in Beurlen, G. and Quadros, L.P, eds., Bioestratigrafia das bacias paleozóicas brasileiras: Rio de Janeiro, Petrobras, pp. 7-14.

Ramos, V.A., Jordan, T.E., Allmendinger, R.W., Mpodozis, C., Kay, S.M., Cortés, J.M., and Palma, M., 1986. Paleozoic terranes of the central Argentine-Chilean Andes: Tectonics, v. 5, no. 6, pp. 855-880.

Russo, A., Archangelsky, S., Andreis, R.A., and Cuerde, A., 1987, Cuenca Chacoparanense, in Archangelsky, S, ed., El sistema carbonifero en la Republica Argentina: Academia Nacional de Ciencias, Cordoba, pp. 197 212.

Rodrigues, R., Soliani Jr., E., Takaki, T., Sato, K., and Kawajita, K., 1993, Cronoestratigrafia isotópica do estrôncio das formações Andirá (Bacia do Amazonas) e Cruzeiro do Sul (Bacia do Acre): Rio de Janeiro, Petrobras, $35 \mathrm{p}$.

Zalán, P.V., Wolff, S., Astolfi, M.A., Vieira, I.S., Conceição, J.C., Appi, V.T., Neto, E.V.S., Cerqueira, J.R., and Marques, A., 1990, The Paraná Basin, Brazil, in Leighton, M.W., Kolata, D.R., Oltz, D.F., and Eidel, J.J. eds., Interior cratonic basins: American Association of Petroleum Geologists, Memoir 51, pp. 681-708.

Edison José Milani, Doctor of Science in Geology, has been an exploration geologist with Petrobras since 1978. He has long been engaged in basin analysis and petroleum geology of several sedimentary provinces of South America. He is a member of the Board of Referees of the Revista Brasileira de Geociências, and is also a visiting professor at Rio de Janeiro State University. He has authored or co-authored 36 published papers, and co-edited the book "Origem e evolução de bacias sedimentares", a reference work on the geology of several sedimentary basins in Brazil.

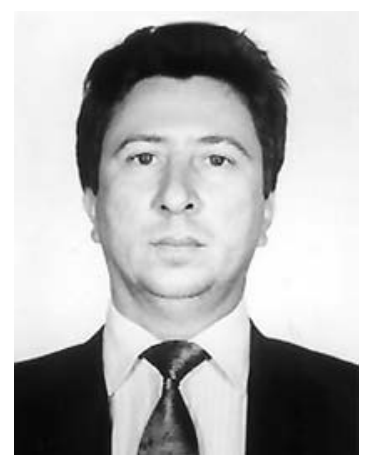

Pedro Victor Zalán, is currently the Coordinator for the Exploration of Deep Water Petroleum Systems for Petrobras in Brazil. His main areas of expertise include structural geology, tectonics and basin analysis. He concentrated his previous domestic activities on the exploration of petroleum in remote, newfrontier, non-conventional areas such as Paleozoic basins with intense magmatism, Proterozoic basins and transtensional basins in transform margins. Zalán holds the titles of Geologist (Federal University of Rio de Janeiro, 1977), M.Sc. and Ph.D., both in Geology (Colorado School of Mines, 1983 and 1984). He has worked for Petrobras since 1978.

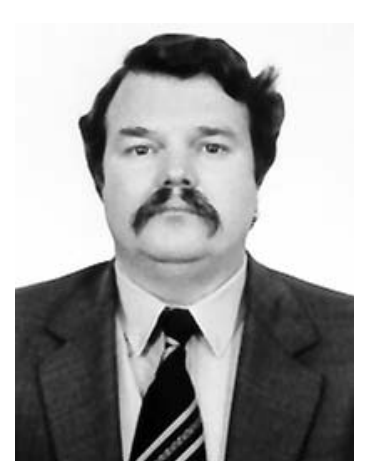

